\title{
DAMPAK KETERKAITAN EKONOMI PULAU SULAWESI, JAWA TIMUR, DAN KALIMANTAN TIMUR TERHADAP EKONOMI WILAYAH
}

\author{
(The Impact of Economic Linkage of Sulawesi Island, East Java, \\ and East Kalimantan on Regional Economic)
}

\author{
Arman*, Setia Hadi**, Noer Azam Achsani**, dan Akhmad Fauzi** \\ *Fakultas Bio Industri Universitas Trilogi, Jl. TMP Kalibata, Jakarta Selatan 12760 \\ E-mail: arman@universitas-trilogi.ac.id dan arman.pwd10@gmail.com \\ **Departemen Agribisnis, Fakultas Ekonomi dan Manajemen, Institut Pertanian Bogor (IPB) \\ Jl. Kampus IPB Dramaga, Bogor 16680 \\ Email: set2460@yahoo.com, achsani@mb.ipb.ac.id, dan fauziakhmad@gmail.com
}

Naskah diterima: 19 Mei 2015

Naskah direvisi: 29 Mei 2015

Naskah diterbitkan: 30 Juni 2016

\begin{abstract}
Economic disparities between regions in Indonesia are still ongoing, whereby Java control of \pm 60 percent of economic activity. This study analyze the effects of the economic linkages among the regions of Sulawesi Island, East Java, and East Kalimantan. North Sulawesi, Central Sulawesi, Southeast Sulawesi, and Gorontalo were aggregated become the Other Sulawesi. South Sulawesi and West Sulawesi were aggregated become South Sulawesi. Data of 2005 is upgraded to be the data of 2011 by using the RAS technique. The analysis showed that the transaction flow of goods between the regions of Other Sulawesi and South Sulawesi is still very small. Both regions are dependent on the supply of the goods from the East Java. Economic linkages between East Kalimantan and Sulawesi Island were influenced by the flow of agricultural commodities and energy. The East Java economic obtain benefit mostly from the economic interaction with Sulawesi Island and East Kalimantan. The result of interaction between regions provide a very large spillover effect on the region of East Java. The spillover Indicating to increase the economic performance of East Java region when economic linkages with the region of Sulawesi Island and East Kalimantan are getting stronger. The impact of economic linkages in all four regions showed East Java obtain greater benefit. However, the performance of economic growth in East Java provide spillover effect which is still very small for Sulawesi and Kalimantan.

Keywords: economic linkage, regional economic, IRIO model
\end{abstract}

\begin{abstract}
Abstrak
Ketimpangan ekonomi antarwilayah di Indonesia masih terus berlangsung, di mana Pulau Jawa menguasai \pm 60 persen aktivitas ekonomi. Penelitian ini menganalisis dampak keterkaitan ekonomi antarwilayah Pulau Sulawesi, Jawa Timur, dan Kalimantan Timur. Sulawesi Utara, Sulawesi Tengah, Sulawesi Tenggara, dan Gorontalo diagregasi menjadi satu unit wilayah menjadi Sulawesi Lain. Sulawesi Selatan dan Sulawesi Barat diagregasi menjadi satu unit wilayah menjadi Sulawesi Selatan. Data dasar tahun 2005 diupgrade ke tahun 2011 dengan menggunakan teknik RAS. Hasil analisis menunjukkan bahwa transaksi aliran barang antara wilayah Sulawesi Lain dengan Sulawesi Selatan masih sangat kecil. Kebutuhan input antara Sulawesi Lain dan Sulawesi Selatan lebih banyak dipasok dari wilayah Jawa Timur. Kedua wilayah tersebut lebih banyak bergantung pasokan aliran barang dari wilayah Jawa Timur. Keterkaitan ekonomi antara Sulawesi Selatan dan Sulawesi Lain terhadap Kalimantan Timur dipengaruhi aliran komoditas pertanian dan energi. Wilayah Sulawesi Selatan dan Sulawesi Lain banyak memasok kebutuhan pangan, sedangkan wilayah Kalimantan memasok kebutuhan energi ke Sulawesi. Wilayah Jawa Timur memperoleh manfaat ekonomi yang paling besar akibat interaksi ekonomi dengan Sulawesi Selatan, Sulawesi Lain, dan Kalimantan Timur. Hasil interaksi memberikan pengaruh spillover yang sangat besar terhadap wilayah Jawa Timur. Pengaruh spillover mengindikasikan kinerja ekonomi wilayah Jawa Timur meningkat bila keterkaitan ekonomi (aliran barang) dengan Pulau Sulawesi dan Kalimantan Timur semakin kuat. Dampak keterkaitan ekonomi pada keempat wilayah menunjukkan Jawa Timur memperoleh manfaat yang lebih besar. Namun kinerja dan pertumbuhan ekonomi Jawa Timur memberikan pengaruh spillover yang masih sangat kecil terhadap wilayah Sulawesi dan Kalimantan.

Kata kunci: ekonomi wilayah, keterkaitan ekonomi, model IRIO
\end{abstract}

\section{PENDAHULUAN}

\section{A. Latar Belakang}

Aktivitas ekonomi dan industri masih terkonsentrasi di Pulau Jawa, di mana sebanyak 63,8 persen industri berada dan beroperasi di Pulau Jawa sedangkan industri di Pulau Sumatera, Kalimantan, Sulawesi, dan kepulauan wilayah timur (NTB, NTT, Maluku, dan Papua) masing-masing hanya 17,7 persen, 7 persen, 5,3 persen dan 6,2 persen (BPS,
2007). Hill, et al. (2008), Rustiadi dan Priyarsono (2010) menyatakan bahwa ketimpangan antarwilayah terus berlangsung hingga saat ini. Pulau Jawa masih sangat mendominasi aktivitas ekonomi sementara wilayah lainnya di indonesia masih jauh tertinggal. Fenomena industrialisasi dan asimetrik pembangunan mendorong terjadinya backwash effect antarwilayah (Myrdal, 1968). Wilayah yang fokus pada aktivitas industri lebih besar menerima manfaat ekonomi 
Tabel 1. Nilai PDRB Berdasarkan Harga Konstan di Masing-Masing Provinsi Periode Tahun 2009-2013

(dalam miliar rupiah)

\begin{tabular}{|c|l|r|r|r|r|r|}
\hline No. & \multicolumn{1}{|c|}{ Wilayah } & \multicolumn{1}{c|}{$\mathbf{2 0 0 9}$} & \multicolumn{1}{c|}{$\mathbf{2 0 1 0}$} & \multicolumn{1}{c|}{$\mathbf{2 0 1 1}$} & \multicolumn{1}{c|}{$\mathbf{2 0 1 2}$} & \multicolumn{1}{c|}{$\mathbf{2 0 1 3}$} \\
\hline 1. & Sulawesi Selatan & $47.326,08$ & $51.199,90$ & $55.093,74$ & $59.718,50$ & $64.284,43$ \\
\hline 2. & Sulawesi Tenggara & $10.768,57$ & $11.653,91$ & $12.698,12$ & $14.020,35$ & $15.040,86$ \\
\hline 3. & Sulawesi Utara & $17.149,62$ & $18.376,82$ & $19.735,47$ & $21.286,58$ & $22.872,16$ \\
\hline 4. & Sulawesi Tengah & $16.207,59$ & $17.626,17$ & $19.230,92$ & $21.007,97$ & $22.979,40$ \\
\hline 5. & Gorontalo & $2.710,73$ & $2.917,49$ & $3.141,45$ & $3.383,82$ & 3646.55 \\
\hline 6. & Kalimantan Timur & $105.564,94$ & $110.953,45$ & $115.489,85$ & $120.085,76$ & $121.990,49$ \\
\hline 7. & Jawa Timur & $320.861,00$ & $342.280,76$ & $366.983,28$ & $393.662,85$ & $419.428,45$ \\
\hline
\end{tabular}

Sumber: BPS (2014a), BPS (2014b), BPS (2014c), BPS (2014d), dan BPS (2014e).

dan perdagangan (LeSage dan Llano 2007). Kuznets (1955) mengatakan perkembangan dan ketimpangan ekonomi ditentukan oleh sistem lembaga politik dan perubahan teknologi (Feldman, et al., 1987). Ekspor memiliki peran penting memperkuat perekonomian (Trinh, et al., 2013). Hausmann and Hidalgo (2011) mengatakan produktivitas ekonomi wilayah sangat ditentukan dengan kompleksitas ekonominya. Semakin kompleks ekonomi wilayah akan mendorong peningkatan ekspor dan selanjutnya meningkatkan pendapatan. Perekonomian wilayah yang kurang kompleks cenderung lebih membutuhkan barang arus masuk (inflow) sehingga berpotensi menciptakan ketergantungan ekonomi dan kebocoran ekonomi secara jangka panjang.

Perekonomian Provinsi Jawa Timur lebih berkembang dari pada Pulau Sulawesi dan Kalimantan Timur. Selain itu, Provinsi Sulawesi Selatan lebih berkembang dibandingkan wilayah lain di Pulau Sulawesi. Perkembangan Sulawesi Selatan tampaknya tidak memberikan pengaruh terhadap wilayah Sulawesi Lain. Sulawesi Selatan lebih mampu berakselerasi dan cepat dalam merespon pembangunan ekonomi dari pada wilayah lain di Pulau Sulawesi (sebagaimana tersaji pada Tabel 1). Fakta tersebut menjadi alasan mengapa Sulawesi Selatan terpisah unit analisisnya dalam Pulau Sulawesi.

Tahun 2013, kontribusi pembangunan Sulawesi Selatan dan Kalimantan Timur masing-masing mencapai 2,41 persen dan 4,58 persen sedangkan Sulawesi Lain hanya 2,42 persen. Jauh berbeda dengan kontribusi Jawa Timur yang mencapai 15,76 persen terhadap indonesia (BPS, 2014). Investasi Penanaman Modal Dalam Negeri (PMDN) dan Penanaman Modal Asing (PMA) sangat dominan di Provinsi Jawa Timur dengan kisaran PMDN sebesar 13,33 persen pada tahun 2010 dan sebesar 12,75 persen pada tahun 2011. Sedangkan PMA berkisar
10,9 persen pada tahun 2010 dan sebesar 6,73 persen pada tahun 2011. Di sisi lain, Sulawesi Lainnya hanya berkisar 0-2 persen. Perbedaan kontribusi dan investasi menjadi pemicu simetrik pembangunan antarwilayah. Penentuan lokasi Pulau Sulawesi, Jawa Timur, dan Kalimantan disebabkan wilayah tersebut memiliki interaksi perdagangan yang lebih kuat dibandingkan wilayah lain (BKPM, 2013).

\section{B. Permasalahan}

Pemerintah telah menetapkan beberapa wilayah sebagai koridor ekonomi berdasarkan kekhasan yang dimiliki oleh setiap wilayah. Koridor ekonomi Sulawesi dicirikan sebagai aktivitas pertanian yang khas sementara aktivitas lainnya sebagai pendukung. Wilayah Kalimantan dicirikan dengan aktivitas pertambangan dan energi sementara aktivitas lainnya sebagai pendukung. Provinsi Jawa Timur dicirikan sebagai aktivitas industrialisasi dan perdagangan, sementara aktivitas lainnya sebagai pendukung. Kontribusi sektor industri pengolahan (25,39 persen) dan perdagangan, hotel, dan restoran (31,04 persen) cukup dominan di Jawa Timur. Besarnya kontribusi sektor industri di Jawa Timur mengindikasikan aktivitas ekonomi yang bernilai tambah tinggi cukup dominan. Wilayah Sulawesi Selatan dan Sulawesi Lain lebih dominan aktivitas pertanian, di mana kontribusi terhadap PDRB di Sulawesi Selatan sebesar 26,97 persen dan Sulawesi Lain sebesar 29,84 persen. Sektor pertanian di kedua wilayah tersebut belum dijadikan instrumen dasar untuk mendorong sektor industri mengingat kontribusi sektor industri masih kecil dari pada sektor pertanian terutama wilayah Sulawesi Lain (7,55 persen).

Kalimantan Timur sangat dominan aktivitas pertambangan dengan kontribusi sekitar 41,5 persen. Kontribusi pertambangan diduga tidak menopang sektor industri karena kontribusi sektor pertambangan di daerah Kalimantan Timur jauh 
Tabel 2. Kontribusi Sektor terhadap Total PDRB Harga Konstan pada Masing-Masing Wilayah Tahun 2010

(dalam Persen)

\begin{tabular}{|l|c|c|c|c|}
\hline \multicolumn{1}{|c|}{ Sektor } & Jatim & Sul-Sel & Kal-Tim & Sul-lainnya \\
\hline Pertanian & 15,00 & 26,97 & 6,58 & 29,84 \\
\hline Pertambangan & 2,27 & 8,77 & 41,56 & 4,81 \\
\hline Industri pengolahan & 25,39 & 13,42 & 27,65 & 7,55 \\
\hline Listrik dan air bersih & 1,36 & 1,03 & 0,33 & 0,74 \\
\hline Bangunan & 3,21 & 5,66 & 3,91 & 10,51 \\
\hline Perdagangan, hotel, \& restoran & 31,04 & 16,99 & 8,89 & 15,32 \\
\hline Angkutan/komunikasi & 7,33 & 9,02 & 5,76 & 10,09 \\
\hline Bank/keuangan/perum & 5,45 & 7,31 & 3,23 & 5,98 \\
\hline Jasa & 8,97 & 10,81 & 2,09 & 15,15 \\
\hline
\end{tabular}

Sumber: BPS (2012).

lebih besar dari pada industri. Tambang batu bara sejatinya menjadi bahan baku dasar untuk energi industri, tetapi industri di Kalimantan Timur masih kecil sehingga batu bara lebih banyak berorientasi ekspor daripada digunakan sebagai bahan dasar energi industri di Kalimantan Timur. Akibatnya, potensi tambang di Kalimantan Timur lebih banyak manfaatnya bagi wilayah industri (terutama di Jawa Timur). Secara rinci kontribusi tiap sektor tersaji pada Tabel 2.

Kekhasan yang dimiliki oleh daerah sangat nampak pada data Tabel 1, di mana suatu daerah memiliki sektor yang unggul. Namun terdapat faktor imperfect (kendala) yang dimiliki oleh setiap daerah dalam mendorong terjadinya interaksi dan keterkaitan ekonomi. Hoover dan Giarratni (1999) menyatakan bahwa kendala yang dimiliki oleh sumber daya alam adalah (1) ketaksempurnaan mobilitas faktor produksi (imperfect factor mobility), (2) ketaksempurnaan pemisahan/pemilahan antarfaktor produksi (imperfect factor divisibility), dan (3) ketaksempurnaan mobilitas barang dan jasa (imperfect mobility of goods and services). Adanya berbagai ketaksempurnaan ini mempertegas pentingnya pertimbangan kerjasama dalam mengolah berbagai sumber daya, aktivitas, dan kinerja ekonomi dalam perencanaan pembangunan.

Di sisi lain, kendala tesebut merupakan salah satu faktor yang menyebabkan simetrik pembangunan dan kebocoran wilayah. Capital flight dan kebocoran wilayah terjadi akibat nilai tambah yang sejatinya diterima wilayah asal tidak terjadi akibat bahan dasar dari wilayah asal (tidak melalui pengolahan teknologi menjadi bahan setengah jadi) langsung diekspor ke wilayah lain. Dampak nilai tambah sektor wilayah asal tidak berpengaruh langsung atau sangat kecil terhadap sektor daerah asal, produktivitas tenaga kerja, serapan tenaga kerja, dan output sektor lainnya. Potensi pendapatan daerah asal dari hasil bahan baku dasar menjadi "hilang" karena dampaknya terhadap aktivitas ekonomi terjadi di daerah tujuan. Hubungan interaksi dan keterkaitan ekonomi menjadi tidak simetrik dan cenderung merugikan daerah asal (penghasil). Beberapa hal yang berpotensi merugikan daerah asal adalah aliran nilai tambah usaha dan aliran nilai tambah pajak tidak langsung cenderung lebih rendah. Berdasarkan uraian tersebut, maka disusun rumusan masalah penelitian:

1. bagaimana keterkaitan ekonomi antarwilayah Sulawesi Lain, Sulawesi Selatan, Jawa Timur, dan Kalimantan Timur?

2. bagaimana aliran nilai tambah pajak tidak langsung dan aliran surplus usaha?

3. bagaimana dampak keterkaitan ekonomi?

\section{Tujuan}

Penelitian ini menganalisis keterkaitan secara multi-regional (obyek/lokasi penelitian lebih dari satu wilayah). Alasan pemilihan lokasi didasarkan pada penciri ekonomi antarwilayah berbeda, yaitu Sulawesi Lain berciri agraris, Jawa Timur berciri industri dan jasa, Kalimantan Timur berciri industri pertambangan dan kehutanan, serta Sulawesi Selatan berciri industri dan pertanian. Perbedaan penciri ekonomi antarwilayah mendorong interaksi ekonomi wilayah untuk memenuhi input antara dan final demand. Kelebihan penelitian ini adalah mampu memformulasi keterkaitan ekonomi antarwilayah yang pencirinya berbeda. 
Tujuan penelitian ini adalah (1) menganalisis keterkaitan ekonomi antarwilayah Sulawesi Lain, Sulawesi Selatan, Jawa Timur, dan Kalimantan Timur, (2) menganalisis nilai tambah upah, pajak tidak langsung, dan surplus usaha, dan (3) menganalisis dampak keterkaitan ekonomi wilayah.

\section{KERANGKA TEORI}

Hill, et al. (2008) menyatakan bahwa keragaman ekonomi dan kondisi sosial indonesia cukup besar, tetapi pertumbuhan ekonomi dan progress sosial belum terjadi secara merata. Belum ada perubahan secara signifikan pada aktivitas ekonomi beberapa daerah di Indonesia. Kegiatan ekonomi masih terkonsentrasi di Pulau Jawa dan Bali dengan perkiraan sebesar 60 persen, sementara di Pulau Sumatera aktivitas ekonomi berkisar 20 persen, selebihnya berkisar 17 persen terjadi di bagian timur Indonesia. Disparitas antardaerah juga cenderung mengalami peningkatan sepanjang tahun 19752004 (PDRB tanpa tambang) sehingga tidak terjadi konvergensi, hanya pengeluaran rumah tangga yang menunjukkan konvergensi ekonomi yang lemah.

Pengaruh aglomerasi ekonomi industri di Jawa Timur (di Pulau Jawa) yang sangat kuat mendorong akselerasi dan aliran nilai tambah ekonomi menjadi lebih besar di wilayah tersebut. Pengembangan aglomerasi didukung dengan faktor demografi yang jauh lebih besar dibandingkan dengan wilayah lain di luar Pulau Jawa. Jumlah penduduk yang besar akan berpengaruh terhadap konsumsi akhir dan skala ekonomi. Isard (1951) menyatakan bahwa aliran komoditas dikaitkan ke dalam 2 hal, yaitu (1) karena adanya ketidaksamaan penyebaran penduduk, pendapatan, dalam arti luas sumber daya dan (2) adanya kegiatan ekonomi skala besar pada wilayah tertentu. Kondisi infrastruktur yang sudah baik di Jawa Timur (Jawa) mempermudah aliran dan transaksi antarwilayah sehingga semakin mendorong efisiensi dan efektivitas interaksi ekonomi.

Chenery, et al. (1962) mengungkap bahwa faktor demografi menyebabkan perubahan output setiap sektor dalam industri yang disebabkan oleh empat hal, yaitu (1) perubahan komposisi domestic demand, (2) perubahan volume ekspor, (3) perubahan volume impor, dan (4) perubahan teknologi serta organisasi. Perubahan permintaan akhir antarwilayah menjadi faktor yang mendorong kekuatan spillover antarwilayah.

Wilayah Jawa Timur (Pulau Jawa) akan mendapatkan keuntungan yang besar akibat faktor demografi, aglomerasi, infrastruktur, dan teknologi. Keuntungan tersebut karena wilayah tersebut mampu menghasilkan output yang sangat besar. Kelebihan penawaran dalam wilayah akan diekspor ke wilayah lain (Sulawesi Selatan, Sulawesi Lain, dan Kalimantan). Besaran output tersebut secara ekonomi terpenuhi karena didukung oleh teknologi dan aglomerasi. Situasi ini semakin memperkuat ekonomi wilayah Jawa Timur dan dalam jangka panjang semakin unggul dengan wilayah lain. Pembangunan aglomerasi di luar wilayah Pulau Jawa (seperti Sulawesi Selatan) belum mampu memenuhi skala ekonomi karena faktor demografi, teknologi, dan konsumsi. Aliran barang dari Jawa Timur masih dinilai lebih ekonomis daripada membangun industri di wilayah Sulawesi. Akibatnya, Jawa Timur memperoleh pengaruh spillover yang besar terhadap kinerja ekonomi Sulawesi maupun Kalimantan Timur. Keterkaitan ekonomi dalam jangka panjang dengan wilayah tersebut akan menyebabkan backwash effect dan kebocoran ekonomi wilayah Sulawesi dan Kalimantan.

Manfaat akses pasar sebesar 10 persen hanya menyebar pada jarak $108 \mathrm{~km}$, sementara manfaat akses pasokan hanya menyebar pada jarak $262 \mathrm{~km}$. Perusahaan yang berada di luar Pulau Jawa terlalu jauh untuk mendapatkan keuntungan dari aglomerasi industri di Pulau utama Jawa. Selanjutnya, manfaat dari aglomerasi yang besar menyebabkan perusahaan enggan untuk beralih ke daerah yang memiliki upah rendah (terutama daerah periphery). Hal ini menjadi faktor penyebab mengapa pemerintah sangat kesulitan untuk memperluas wilayah ekonomi pada daerah yang belum berkembang dengan baik aktivitas ekonominya (Amita dan Cameron, 2004).

Fenomena backwash effect dan kebocoran ekonomi terjadi di negara Asia akibat interaksi dengan negara-negara industri. Kwangmoon, et al. (2011) melakukan penelitian perdagangan bilateral antara Thailand dan Vietnam dengan menggunakan metode IRIO. Asumsi yang digunakan adalah (1) koefisien teknologi setiap negara stabil dan (2) koefisien perdagangan bilateral stabil (dalam jangka pendek). Hasil analisis menunjukkan bahwa pola perdagangan antarnegara masih sangat lemah dibandingkan dengan rest of the world (ROW). Hasil interdependence antarnegara menunjukkan bahwa backward dan forward linkages Thailand lebih besar dibandingkan Vietnam. Hal yang menarik dalam penelitian ini adalah Thailand lebih banyak menggunakan input impor (ROW) untuk menghasilkan produk ekspor (barang dan jasa) dibandingkan Vietnam. Kondisi tersebut menunjukkan bahwa Thailand lebih besar potensi kebocoran ekonominya dibandingkan Vietnam.

Hasil analisis yang diungkap oleh Kwangmoon tersebut menunjukkan bahwa keterkaitan ekonomi antarnegara berciri agraris masih sangat lemah (sebagaimana kasus Sulawesi Selatan dan Sulawesi Lain). Orientasi ekonomi Thailand lebih banyak 
menggunakan input antara dari rest of the world. Aliran nilai tambah, usaha, dan tenaga kerja akan lebih banyak berpengaruh pada negara industri sehingga mengakibatkan kebocoran ekonomi. Negara Thailand dan Vietnam pada jangka panjang memberikan pengaruh spillover terhadap rest of the world. Perekonomian kedua negara tersebut hanya bisa terselesaikan bila membangun industri yang terintegrasi dengan sektor perekonomian lainnya. Pengembangan teknologi dan penelitian yang didukung dengan regulasi kebijakan merupakan solusi jangka panjang untuk mengurangi kebocoran ekonomi dan pengurasan sumber daya.

Fenomena backwash effect tidak hanya terjadi antarwilayah setingkat provinsi dan negara, tetapi dapat terjadi dalam hubungan tingkat kota dengan kabupaten dalam satuan unit provinsi. Hastoto (2003) melakukan analisis disparitas pembangunan regional di Provinsi Sulawesi Utara dan Gorontalo. Salah satu metode yang digunakan adalah menggunakan model gravitasi. Salah satu hasil penelitiannya adalah interaksi spasial yang kuat terjadi antara Kabupaten Minahasa, Kota Manado, dan Kota Bitung. Kota Manado dan Kota Bitung mampu menarik daerah penyangga, yaitu Kabupaten Minahasa menjadi lebih berkembang. Berbeda halnya di Provinsi Gorontalo, interaksi spasial yang kuat antara Kota Gorontalo dengan Kabupaten Gorontalo dan Boalemo belum mampu menarik kedua kabupaten penyangga tersebut menjadi daerah yang berkembang.

Interaksi spasial lainnya yang kuat terjadi pada wilayah Kabupaten Bogor. Arman (2009) menemukan bahwa peran interaksi spasial memberikan pengaruh positif terhadap masalah kemiskinan di Kabupaten Bogor. Bila kerjasama antarwilayah disekitar Kabupaten Bogor dan wilayah sekitar Kabupaten Bogor (seperti Jakarta, Bekasi, dan kecamatan di dalam wilayah Kabupaten Bogor) ditingkatkan sebesar 1 persen, maka akan menurunkan kemiskinan sebesar 7 persen di Kabupaten Bogor. Hal tersebut menunjukkan bahwa pentingnya kerja sama antarwilayah dalam memperkuat pembangunan ekonomi wilayah.

Banyaknya penduduk yang bermukim di Kabupaten Bogor tetapi bekerja di wilayah sekitar Kabupaten Bogor menunjukkan bahwa interaksi spasial memberikan pengaruh perkembangan suatu wilayah. Pasar tenaga kerja Kabupaten Bogor secara tidak langsung "tertolong" dengan kuatnya aglomerasi ekonomi di sekitar Jakarta. Pengaruh aglomerasi menciptakan keterkaitan ekonomi antarwilayah sekitar Kabupaten Bogor sehingga menghasilkan pengaruh spillover yang cukup besar. Oleh karena itu, pemerintah daerah perlu membangun formula inter-regional linkage and partnership sebagai dasar implementasi kebijakan.

\section{METODOLOGI}

\section{A. Jenis Data dan Lokasi Penelitian}

Jenis data yang digunakan adalah data InputOutput Inter Regional (IRIO) tahun 2005 yang terdiri dari 35 sektor. Kemudian data IRIO diRAS (upgrade) ke tahun 2011 karena ketersediaan data hanya tahun 2005. Model IRIO merekam interaksi antarpelaku dan wilayah aktivitas ekonomi yang dikembangkan oleh Wassily Leontif tahun 1930-an (Miller dan Blair, 2009). Penekanan utama dalam penelitian ini adalah berapa besar efek interaksi dan keterkaitan ekonomi antarwilayah. Sedangkan lokasi penelitian yaitu di Sulawesi Lain (Sulawesi Tenggara, Sulawesi Tengah, Sulawesi Utara, dan Gorontalo), Sulawesi Selatan (termasuk Sulawesi Barat), Jawa Timur, dan Kalimantan Timur.

\section{B. Metode Penelitian}

Metode yang digunakan adalah nonsurvei atau pendekatan secara tidak langsung.

Formula matriks Leontif digunakan sebagai alat analisis (1):

$(1-A) X=Y$.

$X=(I-A)^{-1} Y$

Matriks Leontif adalah matriks kunci untuk (1) mengetahui berbagai peramalan model input output dan (2) mengestimasi keterkaitan sektor wilayah dan antarwilayah melalui pendekatan backward lingkage dan forward lingkage (Daryanto dan Hafizrianda, 2010). Chenery and Watanabe (1958) mengestimasi keterkaitan antarsektor diperoleh dari model Leontif, di mana backward lingkage melihat sisi permintaan (demand driven) dan forward lingkage melihat sisi penawaran (supply driven). Formula keterkaitan langsung dan tidak langsung ke belakang dan ke depan pada persamaan (3), di mana $\mathrm{BL}$ adalah keterkaitan langsung dan tidak langsung ke belakang dan FL adalah keterkaitan langsung dan tidak langsung ke depan.

$$
B L_{j}^{R}=\sum_{j=1}^{n} g_{i j} \quad F L_{i}^{c}=\sum_{j=1}^{n} g_{i j}
$$

Selanjutnya yaitu mengestimasi nilai tambah domestik wilayah setiap sektor. Formula matematika diadopsi dari model Morilla, et al. (2006). Nilai tambah yang diestimasi adalah nilai tambah upah, pajak tak langsung, dan surplus usaha.

$$
M=V(I-A)^{-1}
$$

\section{HASIL DAN PEMBAHASAN}

\section{A. Hasil}

Hasil estimasi IRIO 2005 menunjukkan bahwa output wilayah Sulawesi Lain dan Sulawesi Selatan yang mengalir (outflow) ke Jawa Timur masing- 
Tabel 3. Struktur Permintaan Antara Berdasarkan (Kolom) Outflow Domestik Tahun 2005 dan Tahun 2011

\begin{tabular}{|c|c|c|c|c|c|c|c|c|}
\hline \multirow{2}{*}{\multicolumn{2}{|c|}{$\begin{array}{c}\text { Tahun/ } \\
\text { Wilayah }\end{array}$}} & \multirow{2}{*}{$\frac{\text { Sulain }}{\text { (Persen) }}$} & \multirow{2}{*}{$\frac{\text { Sulsel }}{\text { (Persen) }}$} & \multirow{2}{*}{$\frac{\text { Jatim }}{\text { (Persen) }}$} & \multirow{2}{*}{$\frac{\text { Kaltim }}{\text { (Persen) }}$} & \multirow{2}{*}{$\frac{\text { ROI }}{\text { (Persen) }}$} & \multicolumn{2}{|c|}{ Total Outflow } \\
\hline & & & & & & & (Persen) & Rp juta \\
\hline \multirow{6}{*}{ ஜั } & Sulain & & 5,24 & 19,08 & 7,45 & 68,23 & 100 & 2.867 .824 \\
\hline & Sulsel & 4,04 & & 8,94 & 5,77 & 81,25 & 100 & 8.099 .847 \\
\hline & Jatim & 3,32 & 1,68 & & 3,76 & 91,25 & 100 & 38.481 .186 \\
\hline & Kaltim & 5,09 & 5,21 & 3,87 & & 85,83 & 100 & 15.516 .724 \\
\hline & ROI & 13,02 & 18,90 & 58,89 & 9,19 & & 100 & 59.947 .070 \\
\hline & Jumlah & 8,17 & 10,35 & 29,76 & 6,11 & 45,61 & 100 & 124.912 .651 \\
\hline \multirow{6}{*}{ ন্ডি } & Sulain & & 5,03 & 18,70 & 6,18 & 70,09 & 100 & 6.380 .103 \\
\hline & Sulsel & 4,78 & & 7,55 & 5,81 & 81,86 & 100 & 20.128 .857 \\
\hline & Jatim & 1,67 & 0,85 & & 1,81 & 95,67 & 100 & 189.959 .045 \\
\hline & Kaltim & 5,77 & 6,12 & 3,70 & & 84,41 & 100 & 34.704 .025 \\
\hline & ROI & 14,43 & 19,69 & 55,18 & 10,71 & & 100 & 138.372 .731 \\
\hline & Jumlah & 6,70 & 8,04 & 20,63 & 5,09 & 59,55 & 100 & 389.544 .761 \\
\hline
\end{tabular}

Sumber: Tabel IRIO 2005 dan IRIO-RAS 2011 (diolah).

masing sebesar 19,08 persen dan 8,94 persen, lebih besar daripada ke Kalimantan Timur. Output wilayah Jawa Timur secara proporsi ke Sulawesi Lain, Sulawesi Selatan, dan Kalimantan Timur relatif sama, yaitu masing-masing sebesar 3,32 persen, 1,68 persen, dan 3,76 persen. Output Kalimantan Timur yang mengalir ke Sulawesi Lain dan Sulawesi Selatan yaitu 5,09 persen dan 5,21 persen, lebih besar dibandingkan ke Jawa Timur. Interaksi aliran barang mencerminkan bahwa (1) output wilayah Sulawesi Lain dan Sulawesi Selatan lebih besar mengalir ke Jawa Timur dibandingkan ke Kalimantan Timur, (2) output wilayah Kalimantan Timur lebih besar mengalir ke Sulawesi Lain dan Sulawesi Selatan dibandingkan ke Jawa Timur dan (3) output wilayah Jawa Timur relatif sama besarnya mengalir ke Sulawesi Lain, Sulawesi Selatan, dan Jawa Timur. Secara rinci nilai aliran barang antarwilayah tersaji Tabel 3.

Pada tahun 2011, proporsi output yang mengalir (outflow) antarwilayah Sulawesi lain, Sulawesi Selatan, Jawa Timur, dan Kalimantan Timur secara relatif tidak mengalami perubahan signifikan, namun nilai nominal output dan ekspor meningkat di setiap wilayah. Hasil estimasi menunjukkan output yang mengalir antarwilayah tidak berubah secara proporsionalitas, bersifat linearitas, dan aditivitas. Namun hasil tersebut cenderung mendorong output wilayah Jawa Timur jauh lebih besar sehingga tampak terjadi asimetrik pembangunan yang mendorong disparitas pembangunan wilayah. Output yang mengalir ke Sulawesi Selatan, Sulawesi Lain, dan Kalimantan
Timur cukup besar berasal dari wilayah Jawa Timur jika dibandingkan kebutuhan input domestik Jawa Timur dari wilayah Sulawesi dan Kalimantan Timur. Kebutuhan input wilayah Jawa Timur jauh lebih besar daripada wilayah lain karena ekonominya jauh lebih kompleks. Semakin padat (density) aktivitas ekonomi suatu wilayah, maka semakin besar kebutuhan input antara dan besar output perekonomiannya. Selanjutnya untuk mengestimasi ketergantungan suatu wilayah terhadap input antara tercermin pada sisi inflow. Secara rinci nilai transaksi perdagangan (inflow) tersaji pada Tabel 4.

Hasil estimasi tahun 2005 menunjukkan bahwa wilayah Sulawesi Lain dan Kalimantan Timur menggunakan input antara yang lebih besar berasal dari Jawa Timur dibandingkan dengan Sulawesi Selatan. Kondisi tersebut mencerminkan peningkatan output perekonomian di Sulawesi Lain dan Kalimantan Timur memberikan efek terhadap ekonomi wilayah di Jawa Timur. Input antara wilayah Sulawesi Selatan yang berasal dari Kalimantan Timur dan Sulawesi Lain masing-masing sebesar 18,93 persen dan 12,51 persen.

Wilayah Sulawesi Selatan menggunakan input antara lebih besar berasal dari Kalimantan Timur dan Jawa Timur daripada berasal dari Sulawesi Lain. Efek ekonomi wilayah Sulawesi Selatan terhadap Jawa Timur dan Kalimantan Timur relatif sama tetapi memberikan efek yang kecil terhadap wilayah Sulawesi Lain. Input antara Sulawesi Selatan yang berasal dari Jawa Timur dan Kalimantan Timur masing-masing sebesar 4,99 persen dan 6,25 persen. 
Tabel 4. Struktur Permintaan Antara (Persen) Berdasarkan (Baris) Inflow Domestik Tahun 2005 dan Tahun 2011

\begin{tabular}{|c|c|c|c|c|c|c|}
\hline \multicolumn{2}{|r|}{ Tahun/Wilayah } & Sulain & Sulsel & Jatim & Kaltim & ROI \\
\hline \multirow{7}{*}{ ํํํ } & Sulain & & 1,16 & 1,47 & 2,80 & 3,43 \\
\hline & Sulsel & 3,21 & & 1,95 & 6,12 & 11,55 \\
\hline & Jatim & 12,51 & 4,99 & & 18,93 & 61,64 \\
\hline & Kaltim & 7,74 & 6,25 & 1,62 & & 23,38 \\
\hline & $\mathrm{ROI}$ & 76,55 & 87,61 & 94,96 & 72,15 & \\
\hline & Jumlah (persen) & 100 & 100 & 100 & 100 & 100 \\
\hline & Inflow (Rp juta) & 10.199.774 & 12.933 .388 & 37.172 .185 & 7.635 .739 & 56.971 .565 \\
\hline \multirow{7}{*}{ ন্ } & Sulain & & 1,03 & 1,48 & 1,99 & 1,93 \\
\hline & Sulsel & 3,69 & & 1,89 & 5,90 & 7,10 \\
\hline & Jatim & 12,14 & 5,18 & & 17,33 & 78,34 \\
\hline & Kaltim & 7,68 & 6,78 & 1,60 & & 12,63 \\
\hline & ROI & 76,50 & 87,01 & 95,02 & 74,78 & \\
\hline & Jumlah (persen) & 100 & 100 & 100 & 100 & 100 \\
\hline & Inflow (Rp juta) & 26.093 .975 & 31.304 .700 & 80.351 .143 & 19.817 .829 & 231.977.111 \\
\hline
\end{tabular}

Sumber: Tabel IRIO 2005 dan IRIO-RAS 2011 (diolah).

Keterkaitan ekonomi antara Sulawesi Selatan dengan Kalimantan Timur relatif berimbang, di mana input antara Sulawesi Selatan yang berasal dari Kalimantan Timur sebesar 6,25 persen, sebaliknya sebesar 6,12 persen.

Wilayah Sulawesi Lain secara umum memberikan dampak ekonomi terhadap Sulawesi Selatan, Kalimantan Timur, dan Jawa Timur tetapi sebaliknya kinerja ekonomi wilayah lain tidak memberikan efek ekonomi wilayah yang cukup baik terhadap Sulawesi Lain. Interaksi perdagangan secara proporsionalitas dari sisi inflow tidak mengalami perubahan pada tahun 2011.

Dilihat dari sisi inflow dan outflow serta ekspor dan impor, Provinsi Kalimantan Timur relatif berimbang interaksi perdagangan antardaerah dan luar negeri. Nilai outflow lebih besar dari inflow mencerminkan Kalimantan Timur relatif mampu memenuhi rata-rata kebutuhan input kegiatan ekonominya (terjadi hubungan outflow interdependent). Sulawesi Selatan dan Sulawesi Lain memiliki inflow lebih besar daripada outflow dan mengalami defisit perdagangan internasional (di mana impor lebih besar daripada ekspor). Secara umum wilayah Sulawesi Selatan dan Sulawesi Lain masih memerlukan stimulus dan respons dari luar dalam mendorong output perekonomiannya. Provinsi Jawa Timur cukup kuat memengaruhi perekonomian wilayah lain. Jawa Timur mampu mengolah nilai tambah dari input antara yang berasal dari daerah

Tabel 5. Aliran Barang Antarwilayah dan Internasional pada Tahun 2011

\begin{tabular}{|l|r|c|r|r|r|r|}
\hline \multirow{2}{*}{ Wilayah } & \multicolumn{3}{|c|}{ Domestik } & \multicolumn{3}{c|}{ Internasional } \\
\cline { 2 - 8 } & Outflow & Inflow & DO-DI & Ekspor & Impor & E-M \\
\hline Sulain & 6.380 .103 & 26.093 .975 & -197.13 .872 & 38.143 .317 & 47.516 .103 & -9.372 .786 \\
\hline Sulsel & 20.128 .857 & 31.304 .700 & -11.175 .843 & 30.198 .743 & 41.972 .896 & -11.774 .154 \\
\hline Jatim & 189.959 .045 & 80.351 .143 & 109.607 .902 & 431.444 .726 & 525.164 .983 & -93.720 .257 \\
\hline Kaltim & 34.704 .025 & 19.817 .829 & 14.886 .196 & 490.597 .629 & 239.235 .068 & 251.362 .560 \\
\hline
\end{tabular}

Sumber: Tabel IRIO - RAS 2011 (diolah).

Keterangan: DO : domestik outflow.

DI : domestik inflow.

E : ekspor.

$\mathrm{M}$ : impor. 
Tabel 6. Keterkaitan Sektor Sulawesi Lain Antarwilayah Tahun 2005 dan Tahun $2011^{1}$

\begin{tabular}{|c|c|c|c|c|c|c|c|c|}
\hline \multirow{5}{*}{ ํㅗㅇ } & NS & Sektor & $B L$ & Sulain & Sulsel & Jatim & Kaltim & ROI \\
\hline & 31 & Transportasi udara & 2,543 & 1,900 & 0,007 & 0,048 & 0,048 & 0,541 \\
\hline & 20 & $\begin{array}{l}\text { Industri dasar besi, baja, \& } \\
\text { logam dasar bukan besi }\end{array}$ & 2,282 & 1,924 & 0,004 & 0,028 & 0,025 & 0,302 \\
\hline & 25 & Listrik, gas, dan air & 2,230 & 1,702 & 0,006 & 0,027 & 0,042 & 0,454 \\
\hline & 26 & Bangunan & 2,278 & 1,695 & 0,034 & 0,077 & 0,029 & 0,444 \\
\hline \multirow{4}{*}{$\underset{\text { 궁 }}{-1}$} & 31 & Transportasi udara & 2,399 & 1,851 & 0,006 & 0,041 & 0,036 & 0,465 \\
\hline & 25 & Listrik, gas, dan air & 2,151 & 1,685 & 0,006 & 0,025 & 0,033 & 0,402 \\
\hline & 26 & Bangunan & 2,136 & 1,643 & 0,033 & 0,080 & 0,021 & 0,360 \\
\hline & 20 & $\begin{array}{l}\text { Industri dasar besi, baja, \& } \\
\text { logam dasar bukan besi }\end{array}$ & 1,952 & 1,713 & 0,003 & 0,018 & 0,015 & 0,203 \\
\hline
\end{tabular}

Sumber: Tabel IRIO 2005 dan RAS 2011 (diolah), BL, Backward Lingkage.

asal sebesar Rp109,61 triliun serta memenuhi input antarwilayah lain sebesar Rp80,35 triliun. Namun, Provinsi Jawa Timur masih bergantung pada produk impor yang nilainya sangat besar, yaitu Rp93,7 triliun. Jawa Timur tidak sepenuhnya dianggap sebagai wiayah yang kuat perekonomiannya karena fundamental ekonominya masih ditopang oleh impor yang besar. Provinsi Jawa Timur cenderung menciptakan "kebocoran ekonomi" karena nilai impornya sangat besar untuk menunjang aktivitas ekonomi. Secara rinci aliran ekonomi antardaerah dan internasional tersaji pada Tabel 5.

\section{B. Pembahasan}

\section{Keterkaitan Ekonomi Wilayah}

Sektor-sektor yang kuat mendorong perekonomian tahun 2005 di Sulawesi Lain adalah sektor transportasi udara, industri dasar besi, baja dan logam dasar bukan besi, serta industri barang dari logam dan bangunan. Tahun 2011, sektor listrik, gas, dan air menggeser posisi sektor industri dasar besi, baja, dan logam dasar bukan besi. Pergeseran posisi tidak mencerminkan sektor industri logam tidak lagi berkembang tetapi hanya menunjukkan posisi sektor berubah dalam memengaruhi kinerja ekonomi. Secara rinci keterkaitan wilayah tersaji pada Tabel 6.

Hasil estimasi menunjukkan permintaan akhir sektor transportasi udara di Sulawesi Lain mendorong kinerja seluruh sektor sebesar 2,543 (tahun 2005) dan 2,399 (tahun 2011). Efek perekonomian sektor transportasi Sulawesi Lain cukup besar terhadap

\footnotetext{
1,5,5,7,8 Disampaikan oleh Arman, Setia Hadi, Noer Azam Achsani, and Akhmad Fauzi, Model economi linkage between the Sulawesi corridors and in the East Java-East Kalimantan Province. Makalah dipresentasikan di Universitas Putra Malaysia, 26-27 Januari 2015, Kuala Lumpur.
}

Kalimantan Timur $(0,036)$ dan Jawa Timur $(0,041)$ tetapi sangat kecil terhadap Sulawesi Selatan. Sektor yang memperoleh efek besar di Kalimantan Timur adalah sektor pengilangan minyak, sedangkan di Jawa Timur adalah industri pulp dan kertas. Sektor bangunan di Sulawesi Lain memberikan efek ekonomi terhadap Sulawesi Selatan $(0,033)$, Jawa Timur $(0,080)$, dan Kalimantan Timur $(0,021)$. Ekonomi wilayah Sulawesi Lain memberikan pengaruh terhadap kinerja ekonomi Jawa Timur dan Kalimantan Timur tetapi tidak memengaruhi Sulawesi Selatan. Sektor yang memperoleh efek di Jawa Timur dan Sulawesi Selatan adalah industri semen, sedangkan di Kalimantan Timur adalah sektor kehutanan. Selanjutnya, sektor yang memberikan pengaruh terhadap Jawa Timur dan Kalimantan Timur adalah sektor listrik, gas, dan air serta sektor industri dasar besi, baja, dan logam.

Sektor di Sulawesi Selatan yang mendorong kinerja seluruh sektor adalah sektor transportasi udara; industri makanan dan minuman; industri tekstil; dan sektor hotel serta restoran. Secara rinci keterkaitan ekonomi wilayah tersaji pada Tabel 7.

Hasil estimasi menunjukkan industri makanan dan minuman, sektor transportasi udara, dan industri tekstil di Sulawesi Selatan memberikan pengaruh terhadap kinerja output perekonomian di Jawa Timur dan Kalimantan Timur. Besaran pengaruh ditunjukkan oleh peningkatan output sektor makanan dan minuman di Sulawesi Selatan akan meningkatkan output ekonomi di Jawa Timur dan Kalimantan Timur masing-masing sebesar 0,017 dan 0,11 pada tahun 2011. Hal yang sama terjadi pada sektor transportasi udara dan industri tekstil. Industri tekstil di Sulawesi Selatan memberikan pengaruh sebesar 0,013 terhadap perekonomian wilayah di Sulawesi Lain. Hal tersebut menunjukkan kinerja industri tekstil di 
Tabel 7. Keterkaitan Sektor Sulawesi Selatan Antarwilayah Tahun 2005 dan Tahun $2011^{5}$

\begin{tabular}{|c|c|c|c|c|c|c|c|c|}
\hline \multirow{5}{*}{ 오 } & NS & Sektor & BL & Sulsel & Sulain & Jatim & Kaltim & ROI \\
\hline & 31 & Transportasi udara & 2,230 & 1,414 & 0,003 & 0,012 & 0,069 & 0,732 \\
\hline & 12 & Industri makanan \& minuman & 2,228 & 1,963 & 0,005 & 0,020 & 0,015 & 0,225 \\
\hline & 13 & Industri tekstil & 2,174 & 1,467 & 0,013 & 0,033 & 0,030 & 0,631 \\
\hline & 28 & Hotel dan Restoran & 2,056 & 1,640 & 0,009 & 0,013 & 0,008 & 0,386 \\
\hline \multirow{4}{*}{ 공 } & 12 & Industri makanan \& minuman & 2,160 & 1,944 & 0,004 & 0,017 & 0,011 & 0,184 \\
\hline & 31 & Transportasi udara & 2,148 & 1,399 & 0,002 & 0,011 & 0,055 & 0,680 \\
\hline & 13 & Industri tekstil & 2,012 & 1,446 & 0,012 & 0,027 & 0,023 & 0,504 \\
\hline & 28 & Hotel \& restoran & 1,974 & 1,612 & 0,007 & 0,011 & 0,006 & 0,338 \\
\hline
\end{tabular}

Sumber: Tabel IRIO 2005 dan RAS 2011 (diolah).

Sulawesi Selatan memberikan pengaruh yang cukup baik terhadap kinerja ekonomi di Sulawesi Lain, Jawa Timur, dan Kalimantan Timur. Peran Industri tekstil dianggap mampu menciptakan keterkaitan ekonomi antarwilayah.

Sektor yang memperoleh efek terhadap kinerja sektor makanan dan minuman di Sulawesi Selatan adalah sektor tanaman perkebunan dan peternakan, sedangkan di Kalimantan Timur adalah sektor pengilangan minyak. Sektor yang memperoleh efek di Sulawesi Selatan adalah sektor padi dan peternakan. Sektor di Jawa Timur yang mendorong output perekonomian adalah sektor transportasi udara, industri kelapa sawit, industri mesin dan peralatan, dan sektor bangunan. Secara rinci keterkaitan wilayah tersaji pada Tabel 8.

Hasil estimasi menunjukkan kinerja sektor di Jawa Timur hanya memberikan pengaruh ekonomi wilayah ke Kalimantan Timur pada tahun 2005. Kinerja sektor di Jawa Timur pada tahun 2011 hanya memberikan pengaruh ekonomi wilayah sangat kecil di Sulawesi Lain, Sulawesi Selatan, dan Kalimantan
Timur. Kondisi tersebut mencerminkan proporsi input antara dari wilayah Sulawesi Lain, Sulawesi Selatan, dan Kalimantan Timur sangat kecil digunakan oleh Jawa Timur. Output perekonomian Jawa Timur yang jauh lebih besar juga menunjukkan ekonominya lebih kompleks daripada wilayah lain. Ekonomi kompleks ditandai dengan ragam aktivitas industri berada di Jawa Timur yang mampu menghasilkan berbagai macam output.

Kinerja sektor yang kuat tahun 2005 berbeda dengan tahun 2011. Tahun 2005, sektor yang kuat pengaruh ekonominya adalah industri makanan minuman; transportasi udara; listrik, gas, dan air; serta industri alat transportasi dan perbaikan. Sektor tersebut akan mendorong output seluruh perekonomian masing masing sebesar 2,635, 2,089, 2,008, dan 2,008. Tahun 2011, sektor yang kuat mendorong kinerja ekonomi adalah industri dasar besi, baja, dan logam dasar bukan besi; sektor besi dan baja; industri mesin dan peralatan; serta industri alas kaki. Secara rinci keterkaitan wilayah tersaji pada Tabel 9.

Tabel 8. Keterkaitan Sektor Jawa Timur Antarwilayah Tahun 2005 dan Tahun $2011^{6}$

\begin{tabular}{|c|c|c|c|c|c|c|c|c|}
\hline \multirow{5}{*}{ 号 } & NS & Sektor & BL & Jatim & Sulain & Sulsel & Kaltim & ROI \\
\hline & 31 & Transportasi udara & 2,469 & 1,728 & 0,001 & 0,001 & 0,415 & 0,324 \\
\hline & 26 & Bangunan & 2,108 & 1,866 & 0,002 & 0,001 & 0,051 & 0,188 \\
\hline & 10 & Industri kelapa sawit & 2,210 & 1,466 & 0,015 & 0,001 & 0,025 & 0,704 \\
\hline & 22 & Industri mesin \& peralatan & 2,231 & 1,414 & 0,001 & 0,001 & 0,022 & 0,795 \\
\hline \multirow{4}{*}{ ت্ } & 22 & Industri mesin \& peralatan & 2,130 & 1,370 & 0,000 & 0,001 & 0,002 & 0,758 \\
\hline & 31 & Transportasi udara & 2,071 & 1,633 & 0,001 & 0,001 & 0,004 & 0,432 \\
\hline & 10 & Industri kelapa sawit & 1,997 & 1,396 & 0,011 & 0,000 & 0,004 & 0,586 \\
\hline & 26 & Bangunan & 1,889 & 1,737 & 0,002 & 0,001 & 0,002 & 0,147 \\
\hline
\end{tabular}

Sumber: Tabel IRIO 2005 dan RAS 2011 (diolah). 
Tabel 9. Keterkaitan Sektor Kalimantan Timur Antarwilayah Tahun 2005 dan Tahun $2011^{7}$

\begin{tabular}{|c|c|c|c|c|c|c|c|c|}
\hline \multirow{5}{*}{ นัญ } & NS & Sektor & BL & Kaltim & Sulain & Sulsel & Jatim & ROI \\
\hline & 12 & Industri makanan \& minuman & 2,365 & 1,883 & 0,057 & 0,008 & 0,216 & 0,201 \\
\hline & 31 & Transportasi udara & 2,089 & 1,769 & 0,001 & 0,001 & 0,019 & 0,298 \\
\hline & 25 & Listrik, gas, \& air & 2,008 & 1,919 & 0,001 & 0,001 & 0,006 & 0,082 \\
\hline & 23 & Industri alat transportasi \& perbaikan & 2,008 & 1,403 & 0,001 & 0,001 & 0,140 & 0,463 \\
\hline \multirow{4}{*}{ 공 } & 20 & $\begin{array}{l}\text { Industri dasar besi, baja, \& logam } \\
\text { dasar bukan besi }\end{array}$ & 2,374 & 2,038 & 0,001 & 0,000 & 0,303 & 0,032 \\
\hline & 21 & Industri besi, baja & 2,374 & 2,038 & 0,001 & 0,000 & 0,303 & 0,032 \\
\hline & 22 & Industri mesin \& peralatan & 2,374 & 2,038 & 0,001 & 0,000 & 0,303 & 0,032 \\
\hline & 14 & Industri alas kaki & 2,374 & 2,038 & 0,001 & 0,000 & 0,303 & 0,032 \\
\hline
\end{tabular}

Sumber: Tabel IRIO 2005 dan RAS 2011 (diolah).

Hasil estimasi menunjukkan bahwa ekonomi wilayah Kalimantan Timur memberikan efek terhadap kinerja sektor di Jawa Timur, tetapi efeknya kecil ke Sulawesi Selatan dan Sulawesi Lain. Hanya industri makanan dan minuman yang memberikan pengaruh terhadap Sulawesi Selatan dan Sulawesi Lain yaitu sebesar 0,008 dan 0,057 (tahun 2005). Pada tahun 2011, efek ekonomi wilayah ke Jawa Timur adalah kuat, sedangkan dengan Sulawesi Selatan dan Sulawesi Lain semakin kecil.

\section{Aliran Pengganda Upah}

Aliran pengganda upah dianalisis dalam rangka mengetahui berapa besar pengaruh pengganda upah akibat adanya transaksi aliran barang dan keterkaitan ekonomi antarwilayah. Hasil estimasi menunjukkan sektor pemerintahan umum dan pertahanan memiliki pengganda upah yang tinggi di Sulawesi Lain, Jawa Timur, dan Kalimantan Timur. Sementara di Sulawesi Selatan, ternyata sektor jasa-jasa lain yang memiliki nilai pengganda tinggi. Secara rinci nilai pengganda upah wilayah tahun 2011 tersaji pada Tabel 10.
Sektor pemerintahan umum dan pertahanan memiliki pengganda upah yang tinggi karena belanja modal lebih banyak kembali pada kegiatan instansi daripada berdampak pada kinerja dan output ekonomi. Sektor pemerintahan umum dan pertahanan tidak sensitif terhadap kinerja ekonomi dan tidak responsif meningkatkan output perekonomian. Situasi ini menunjukkan terjadi "paradoks" ekonomi karena aliran nilai tambah bukan pada sektor yang strategis mendorong kinerja ekonomi.

Sektor komunikasi dan angkutan darat termasuk sektor yang memiliki nilai pengganda upah yang cukup tinggi di Sulawesi Lain. Sektor pengganda upah di Sulawesi Selatan yang tinggi adalah sektor jasa-jasa, industri alat angkutan dan perbaikan, dan industri semen. Sektor pertambangan minyak, gas, dan panas bumi dan sektor padi termasuk sektor yang memiliki pengganda upah tinggi di Jawa Timur. Nilai pengganda upah tinggi sektor padi di Jawa Timur mencerminkan biaya proporsional yang dikeluarkan sektor padi untuk upah lebih tinggi daripada

Tabel 10. Koefisien Pengganda Upah/Gaji Tahun $2011^{8}$

\begin{tabular}{|c|c|c|c|c|c|}
\hline \multicolumn{3}{|c|}{ Sulawesi Lain } & \multicolumn{3}{|c|}{ Sulawesi Selatan } \\
\hline NS & Sektor & Koef & NS & Sektor & Koef \\
\hline 34 & Pemerintahan umum \& pertahanan & 0,669 & 35 & Jasa-jasa lain & 0,933 \\
\hline 32 & Komunikasi & 0,373 & 23 & Industri alat angkutan \& perbaikan & 0,371 \\
\hline 29 & Angkutan darat & 0,315 & 19 & Industri semen & 0,339 \\
\hline \multicolumn{3}{|c|}{ Jawa Timur } & \multicolumn{3}{|c|}{ Kalimantan Timur } \\
\hline 34 & Pemerintahan umum \& pertahanan & 0,699 & 34 & Pemerintahan umum \& pertahanan & 0,933 \\
\hline 7 & Pertambangan minyak, gas, \& panas bumi & 0,641 & 3 & Tanaman perkebunan & 0,292 \\
\hline 1 & Padi & 0,540 & 26 & Bangunan & 0,261 \\
\hline
\end{tabular}

Sumber: Tabel IRIO-RAS 2011 (diolah). 
Tabel 11. Koefisien Pengganda Pajak Tidak Langsung Tahun 2011

\begin{tabular}{|c|l|c|c|l|l|c|}
\hline \multicolumn{2}{|c|}{ Sulawesi Lain } & \multicolumn{4}{c|}{ Sulawesi Selatan } \\
\hline NS & \multicolumn{1}{|c|}{ Sektor } & Koef & NS & \multicolumn{2}{c|}{ Sektor } & Koef \\
\hline 33 & Lembaga keuangan & 0,045 & 19 & Industri semen & 0,086 \\
\hline 8 & $\begin{array}{l}\text { Pertambangan batu bara, biji logam, \& } \\
\text { penggalian }\end{array}$ & 0,041 & 11 & Industri pengolahan hasil laut & 0,071 \\
\hline 28 & Hotel dan restoran & 0,029 & 27 & Perdagangan & 0,054 \\
\hline \multicolumn{2}{|c|}{ Jawa Timur } & 0,181 & 33 & Lembaga keuangan & 0,046 \\
\hline 10 & Industri kelapa sawit & 0,106 & 27 & Perdagangan & 0,044 \\
\hline 12 & Industri makanan minuman & 0,106 & 12 & Industri makanan minuman & 0,044 \\
\hline 25 & Listrik, gas, dan air bersih &
\end{tabular}

Sumber: Tabel IRIO-RAS 2011 (diolah).

surplus usaha padi. Hal ini bisa terjadi karena sektor padi tidak responsif dan sensitif terhadap kinerja ekonomi di Jawa Timur. Nilai pengganda upah tinggi di Kalimantan Timur adalah sektor tanaman perkebunan dan bangunan.

\section{Aliran Pengganda Pajak Tidak Langsung}

Aliran pengganda pajak tidak langsung dianalisis dalam rangka mengetahui berapa besar pengaruh transaksi aliran barang dan keterkaitan ekonomi antarwilayah terhadap aliran pengganda pajak tidak langsung. Hasil estimasi menunjukkan bahwa sektor yang memiliki nilai pengganda pajak tinggi adalah sektor sekunder yang umumnya menjadi sumber utama pemerintah memperoleh penghasilan pajak. Di Sulawesi Lain, sektor terbesar penghasil pengganda pajak adalah sektor lembaga keuangan; pertambangan batu bara, biji logam, dan penggalian; dan sektor hotel serta restoran. Di Sulawesi Selatan, sektor industri semen merupakan sektor penghasil pengganda pajak terbesar. Di Jawa Timur, sektor penghasil pajak terbesar adalah sektor industri kelapa sawit. Di Kalimantan Timur, sektor penghasil pengganda pajak terbesar adalah sektor lembaga keuangan. Secara rinci nilai pengganda pajak tidak langsung tahun 2011 tersaji pada Tabel 11.

\section{SIMPULAN DAN SARAN}

\section{A. Simpulan}

Keterkaitan ekonomi wilayah Sulawesi Lain relatif rendah daripada wilayah lain. Keterkaitan ekonomi wilayah Sulawesi Selatan relatif lebih baik daripada Sulawesi Lain. Meskipun Sulawesi Selatan dan Sulawesi Lain berada pada 1 hamparan pulau, namun orientasi interaksi dan keterkaitan ekonomi masih kecil. Input antarkedua wilayah tersebut lebih banyak berasal dari Jawa Timur. Keterkaitan ekonomi Sulawesi Selatan dan Sulawesi Lain yang tinggi terhadap Jawa Timur memberikan pengaruh spillover terhadap kinerja ekonomi Jawa Timur. Hal ini menunjukkan kinerja ekonomi di Sulawesi Selatan dan Sulawesi Lain memberikan pengaruh kinerja ekonomi wilayah Jawa Timur, tetapi sebaliknya pengaruhnya kecil. Peran perekonomian Jawa Timur sangat besar karena outflow-nya yang digunakan wilayah lain besar. Pola ekonomi wilayah Kalimantan Timur relatif baik, namun lebih banyak dipengaruhi oleh sektor pertambangan. Sebagian besar input antara dari sektor pertambangan di Kalimantan Timur banyak digunakan sebagai input sektor transportasi, energi listrik, dan industri. Namun sektor lainnya di Kalimantan Timur memiliki keterkaitan yang lemah karena sebagian besar berasal dari wilayah lain. Industri pengolahan di Kalimantan Timur kinerjanya masih rendah dibandingkan dengan sektor industri di Sulawesi Selatan dan Jawa Timur.

Manfaat dampak interaksi dan keterkaitan antarwilayah tahun 2011 adalah (a) Sulawesi Lain memberikan pengaruh ekonomi wilayah ke Jawa Timur dan Kalimantan Timur tetapi sangat kecil efeknya ke Sulawesi Selatan. Hal ini terjadi karena input antara kegiatan ekonomi lebih banyak berasal dari Jawa Timur dan Kalimantan Timur. Bila kinerja ekonomi terus membaik di Sulawesi Lain, maka akan meningkatkan penggunaan input antara dari Jawa Timur dan Kalimantan Timur sehingga memberikan pengaruh spillover ekonomi, (b) Sulawesi Selatan memberikan pengaruh ekonomi wilayah ke Jawa Timur dan Kalimantan Timur, tetapi sangat kecil efeknya ke Sulawesi Lain. Input antara yang digunakan oleh kegiatan ekonomi di Sulawesi Selatan sebagian besar berasal dari Jawa Timur sedangkan dari Sulawesi Lain masih kecil. Beberapa input antara yang berasal dari Jawa Timur di antaranya adalah industri tekstil dan industri makanan dan minuman, (c) efek ekonomi wilayah Jawa Timur pada tahun 
2011 sangat kecil ke wilayah lain. Wilayah Jawa Timur lebih banyak menggunakan input antara dari daerah asal. Industrialisasi dan aglomerasi memengaruhi keterkaitan sektor. Berbagai kegiatan industri menjadi pemasok industri lain sebagai input antara. Industrialisasi dan aglomerasi meningkatkan keragaman input antara sehingga merangsang industri tumbuh di wilayah Jawa Timur. Akibatnya, kinerja ekonomi wilayah Jawa Timur tidak berpengaruh besar terhadap perekonomian Sulawesi Selatan, Sulawesi Lain, dan Kalimantan Timur, dan (e) Kalimantan Timur lebih banyak memberikan efek ke Jawa Timur daripada ke Sulawesi Selatan dan Sulawesi Lain.

Sedangkan dampak aliran nilai pengganda sektor, yaitu (a) nilai pengganda pendapatan tinggi adalah sektor pemerintahan umum dan pertahanan pada tahun 2005 dan tahun 2011, kecuali di Sulawesi Selatan pada sektor jasa. Situasi tersebut menunjukkan bahwa terjadi paradoks ekonomi di wilayah Sulawesi Lain, Kalimantan Timur, dan Jawa Timur. Industri makanan dan minuman serta industri pertambangan sejatinya yang memperoleh aliran nilai tambah tinggi, namun yang terjadi adalah sektor pemerintahan umum dan pertahanan yang memperoleh aliran nilai tambah tinggi dan (b) nilai pengganda pajak tidak langsung yang tinggi di Sulawesi Lain adalah sektor lembaga keuangan serta pertambangan batubara, biji logam, dan penggalian, di Sulawesi Selatan adalah industri semen dan industri pengolahan hasil laut, di Jawa Timur adalah Industri kelapa sawit dan industri makanan dan minuman, dan di Kalimantan Timur adalah lembaga keuangan dan perdagangan.

\section{B. Saran}

Diperlukan analisis ekonomi kompleksitas untuk menilai tingkat density ekonomi di suatu wilayah. Semakin kompleks produk dan pengetahuan yang dihasilkan oleh perekonomian wilayah maka semakin berkembang wilayah tersebut. Analisis kompleksitas mampu mengestimasi secara lebih jelas manfaat interaksi ekonomi antarwilayah dan negara. Lebih jauh, keterkaitan sektor dan industri turunan dapat diestimasi secara akurat untuk mengetahui seberapa besar kompleksitasnya. Saran kedua, penggunaan metode computable general equilibrium (CGE) sangat penting untuk menilai peran utama dan dampak kinerja sektor strategis terhadap keterkaitan sektor ekonomi wilayah dan antarwilayah. Penggunaan metode CGE akan lebih memudahkan simulasi sektor strategis di suatu wilayah.

\section{DAFTAR PUSTAKA}

\section{Buku}

Daryanto, A. dan Hafizrianda, Y. (2010). Model-Model kuantitatif: Untuk perencanaan pembangunan ekonomi daerah. Bogor: IPB.

Hausmann, R., Hidalgo, C. A., Bustos, S., Coscia, M., Chung, S., Jimenez, J., Simoes, A., and Yildirim, M. A. (2011). The Atlas of economic complexit: Mapping paths to prosperity. Center for Internationl Development at Harvard University. Massachusetts.

Miller, R. E. and Blair, P. D (2009). Input output analysis: Foundations and extensions. Cambridge University Press.

Myrdal, G. (1968). Asian drama: An inquiry into the poverty of nations, London: Allan Lane.

Rustiadi, E. and Priyarsono, D. S. (2010). Regional development in Indonesia: Problems, policies, and prospect. regional development in indonesia. Bogor: Crestpent Press.

Badan Pusat Statistik. (2007). Sensus ekonomi nasional. Jakarta: BPS.

Badan Pusat Statistik. (2012). Perkembangan beberapa indikator utama sosial-ekonomi Indonesia. Jakarta: BPS.

Badan Pusat Statistik. (2014a). Sulawesi Utara dalam angka. Manado: BPS Provinsi Sulawesi Utara.

Badan Pusat Statistik. (2014b). Gorontalo dalam angka. Gorontalo: BPS Provinsi Gorontalo.

Badan Pusat Statistik. (2014c). Sulawesi Tengah dalam angka. Palu: BPS Provinsi Sulawesi Tengah.

Badan Pusat Statistik. (2014d). Sulawesi Tenggara dalam angka. Kendari: BPS Provinsi Sulawesi Tenggara.

Badan Pusat Statistik. (2014e). Sulawesi Selatan dalam angka. Makassar: BPS Provinsi Sulawesi Selatan.

\section{Jurnal dan Working Paper}

Amiti, M. and Cameron, L. (2004). Economic geography and wages: The case of Indonesia. IMF Working Paper.

Chenery, H. B. and Watanabe, T. (1958). International comparasions of the structure of production. Econometrica, Vol. 26, 487-521. 
Chenery, H. B., Shishido, S and T. Watanabe. (1962). The pattern of Japanese growth 1914-1954. Econometrica, 30(1), 98-139.

Feldman, S. J., McClain, D and Palmer, K. (1987). Source of structural change in The United States 1963-1978: An input output perspective. Review of Economics and Statistics, Vol. 69, 503-510.

Hill, H., Resosudarmo, B., and Vidyattama. (2008). Indonesia's changing economic geography. CCAS Working Paper No. 12. Doshisha University.

Isard, W. (1951). Interregional and regional inputoutput analysis: A model of a space-economy. The Review of Econoic and Statistic, Vol. 33, 318328.

Kuznets, S. (1955). Economic growth and income inequality. The American Economic Association, 45(1), 1-28.

Kwangmoon, K., Secretario, F., Trinh, B., and Kaneko, H. (2011). Developing a bilateral input-output table in the case of Thailand and Vietnam: Methodology and application. $19^{\text {th }}$ International Input-Output Conference-Austria.

LeSage, J. P., and Llano, C. (2007). A spatial interaction model with spatially structured origin and destination effect. Department of Finance an Economics, Texas State University-SanMarcos.
Morilla, C. G., Diaz-Salazar, G. L., and Cardenete, M. A. (2006). Economic and environmental efficiency using a social accounting matrix. International Society For Environmental Epidemiology Vol. 60, 774-786.

Trinh, B., Manh Hung, D., and Van Huan, N. (2013). Vietnam inter-regional input-output analysis: The bi-regional and 8-regional cases of Vietnam. Journal of Contemporary Management, Vol. 10, 11-20.

Tesis

Arman. (2009). Peran pembangunan manusia/sosial dan interaksi spasial dalam penanggulangan kemiskinan dan pengangguran: Kasus Kabupaten Bogor. Tesis. Fakultas Pertanian, Institut Pertanian Bogor. Bogor.

Hastoto, E. (2003). Analisis disparitas pembangunan regional di Provinsi Sulawesi Utara dan Provinsi Gorontalo. Tesis. Fakultas Ekonomi dan Manajemen, Institut Pertanian Bogor. Bogor. 